\title{
PREVALENSI PARASIT CACING SALURAN PENCERNAAN PADA KUCING LIAR DI KOTA BANYUWANGI
}

\section{Prevalence of Gastrointestinal Helminth Parasite in Stray Cat in Banyuwangi City}

\author{
Aditya Yudhana ${ }^{1 *}$, Ratih Novita Praja ${ }^{2}$ \\ ${ }^{1}$ Laboratorium Parasitologi, Departemen Parasitologi Veteriner, \\ ${ }^{2}$ Laboratorium Bakteriologi dan Mikologi, Departemen Mikrobiologi Veteriner, \\ Kampus C UNAIR Jln. Mulyorejo, Surabaya, Jawa Timur, Indonesia, 60115 \\ Telp.(031) 5993016, Fax.(031) 5990315 \\ *Corresponding author: aditvet@gmail.com
}

\begin{abstract}
Abstrak
Penelitian ini bertujuan untuk mengetahui angka prevalensi kasus infeksi cacing saluran cerna dan mengidentifikasi jenis cacing pada kucing liar di wilayah Kota Banyuwangi. 126 sampel feses kucing yang berasal dari wilayah Kota Banyuwangi dikoleksi dan disimpan dalam larutan formaldehide 10\%. Seluruh sampel feses tersebut diperiksa dengan dua metode berbeda yaitu metode natif dan metode pengapungan untuk mengidentifikasi telur cacing yang terdapat pada feses kucing. Pada penelitian ini teridentifikasi tiga genus cacing yang menginfeksi kucing liar di wilayah Kota Banyuwangi yaitu Toxocara, Ancylostoma, dan Diphyllobothrium. Hasil penelitian ini menunjukkan bahwa prevalensi kasus infeksi cacing saluran cerna pada kucing liar wilayah Kota Banyuwangi masih tinggi, yaitu Toxocara Spp (43,65\%), Ancylostoma Spp (3,96\%), dan Diphyllobothrium Spp (52,38\%). Untuk itu diperlukan program pengendalian yang tepat terhadap kasus infeksi cacing saluran cerna pada kucing liar di wilayah Kota Banyuwangi.
\end{abstract}

Kata kunci: cacing saluran cerna, kucing liar, prevalensi, Kota Banyuwangi

\begin{abstract}
This research aims to determine the prevalence rate of gastrointestinal helminthes and identify the type of helminthes from stray cats in Banyuwangi City area. 126 cat's fecal samples were collected from all around Banyuwangi City area and stored in $10 \%$ formaldehide solution. All fecal samples were examined by two different method which is native and floatation method to identify the helminth eggs found in cat feces. Three genera of helminth parasites were indentified in this research result from stray cats in Banyuwangi City assigned as Toxocara, Ancylostoma, and Diphyllobothrium. The result of this research indicate that the prevalence of gastrointestinal parasites infections in stary cats in Banyuwangi City is still high, assigned as Toxocara Spp (43,65\%), Ancylostoma Spp (3,96\%) and Diphyllobothrium Spp (52,38\%). Based on that result, proper control program is highly recommended for gastrointestinal helminth parasites case in Banyuwangi City.
\end{abstract}

Key words: gastrointestinal helminth, stray cat, prevalence, Banyuwangi City

\section{INTRODUCTION}

The prevalence of helminthes as intestinal parasites can vary due to geographical region. Several factors could affect the frequency of a species of parasite in a population. Presence of veterinary care, habits of the local animal populations, season of the year and the cat population composition (Abu-Madi et al.,2008). Internal parasites can decrease endurance by absorbing essential nutrients and interfering with vital organs (Agustina, 2013), the worm infection can make cats more susceptible to various diseases (Ward, 2009). Gastrointestinal parasites constitute a major source of diseases for cats in the tropics, and have been recognized as important public health problems in several parts of the world (Raji et al., 2013).

Many surveys regarding cat helminthes have been conducted in the world since long time ago. The data of helminthes prevalence in fecal cats reported in Republic of Korea was $82.2 \%$. More than 29 helminthes species including adults or eggs were detected in visceral and fecal samples 
of the examined cats. A variety of Cestodes, including Spirometra erinacei, Taenia taeniaeformis and unidentified species of tapeworm were detected (Sohn and Chai, 2005). In Romania reported that the overall prevalence of endoparasites in household cats was $34.3 \%$ (Mircean et al., 2010), the data also reported in Lisbon that found intestinal parasites in 23/74 samples and identified as Toxocara cati, Isospora felis, Ancylostoma tubaeforme, Dipylidium caninum, Uncinaria stenocephala and T. Leonine (Duarte et al., 2010). In Japan was reported, $43.1 \%$ cats infected by internal parasites (Yamamoto et al., 2009). Studies of gastrointestinal parasites of cats in several parts of the countries have been limited to the stray cat population (Raji et al., 2013). The data about parasites in cats in part area of Bali which is nearest area from Banyuwangi City have been reported, the prevalence of $T$. cati in cats in Denpasar have been reported $32.5 \%$ was household cats and $65 \%$ was stray cats, overall prevalence was $48,8 \%$ (Nealma et al., 2013).

In Banyuwangi City, there is little information available on the prevalence and distribution of gastrointestinal parasites for cats and no data on the intensity of infection in the cat population. More studies are needed to determine the gastrointestinal parasite in cats population in Banyuwangi City and epidemiological data are needed to develop effective control measures for zoonotic parasites. The objective of this study was to determine the prevalence of helminthes as gastrointestinal parasites from stray cats in Banyuwangi City.

\section{MATERIALS AND METHODS}

A total of 126 fecal samples collected from stray cats in all around Banyuwangi City area divided by north, south, central, west, and east area to represent the condition of Banyuwangi City (Kampung Mandar, Kertosari, Pakis, Singotrunan, and Kepatihan District). Stray cats caught by pet cargo and put in cage until defecation, during the periods cats given feed and ad libitum of water. Fecal samples were put in a tube and preserved in $10 \%$ formaldehide solution (Marti and Escher, 1990). Concentration method was used to identify the eggs of helminthes by native and flotation techniques and observed under a binocular microscope at 100x magnification. Helminthes eggs were identified based on structural and morphometric features. In addition to qualitative diagnosis, an indirect measure of parasite intensity was obtained by counting eggs, expressed as eggs/gram of faeces. All of the data were analyzed descriptively by using statistic program (Glinz et al., 2010).

\section{RESULTS AND DISCUSSION}

The prevalence of gastrointestinal helminthes in stary cats in Banyuwangi City was presented in Table 1. The result showed that the prevalence of Toxocara Spp in Banyuwangi City was relatively high $(43,65 \%)$, compare to other previous research in Netherland was 2,9\% (Overgaauw, 1997), 39.9\% in Poland (Luty, 2001) and $43 \%$ in Colombia (Echeverry et al., 2012). Zibaei et al. (2007) in Iran reported 92.9\% of stray cats infected by Toxocara Spp. The prevalence of Toxocara Spp in cats in Europe have been reported, Epe et al. (2004) detected Toxocara cati eggs in $3.9 \%$ of feline fecal samples in Germany, In Italy, Riggio et al. (2013) found Toxocara cati in $22 \%$ and hookworm eggs in $1.2 \%$ of feline fecal samples. In Spain, Gracenea et al. (2009) found Toxocara cati eggs in $22 \%$ of feline fecal samples with distinct higher incidence in kittens. And in Romania Toxocara cati were infected $20.3 \%$ of household cats (Mircean et al., 2010). This result is in agreement with the research conducted in Denpasar, (Nealma et al., 2013) reported 60\% stray cats infected by Toxocara cati.

Table 1. Prevalence of Gastrointestinal Helminthes in Stray Cats in Banyuwangi City

\begin{tabular}{lcc}
\hline \multicolumn{1}{c}{ Genus Identified } & $\begin{array}{c}\text { Positive } \\
\text { Samples }\end{array}$ & $\begin{array}{c}\text { Prevalence } \\
(\%)\end{array}$ \\
\hline Toxocara Spp. & $55 / 126$ & 43,65 \\
Ancylostoma Spp. & $5 / 126$ & 3,96 \\
Diphyllobothrium & $66 / 126$ & 52,38 \\
Spp. & & \\
\hline
\end{tabular}

The age of the cat was the most significant risk factor for Toxocara Spp in the research 
result analysis. The high prevalence of Toxocara Spp observed in cats less than six months old (< 6 months) was expected and may be due to the trans-mammary passage of the parasite to the kittens (Labarthe et al., 2004). This could play a significant role in contributing to the incidence of cutaneous larva migrans in the human population. Toxocara cati is an ascarid nematode which was the next most common intestinal parasite observed in this study with a relatively high prevalence of $43,65 \%$. The high prevalence of Toxocara cati infection recorded poses a high risk to humans in view of the large number of eggs about 200.000 eggs produced per day by a female of this parasite that are deposited in the soil along with cat's faeces. These eggs can survive for a long time in the environment can be accidentally ingested by humans in which they can cause visceral larva migrans or human toxocariasis due to larva migration, a commonly reported zoonotic helminthiasis (Holland and Smith, 2006).

The prevalence of Ancylostma Spp which worldwide known as hookworm in stray cats in Banyuwangi City was $3,96 \%$. It was lower than in Brazil that was 94,2\% identified three species; A. caninum (67.3\%), A. braziliense $(21.1 \%)$ and A. tubaeforme (9.6\%) (Coelho et al., 2011) and the recent study reported $60.69 \%$ cats in Brazil were infected by Ancylostma Spp (Ramos et al., 2013). The prevalence in Korea was $33 \%$ in feral cats (Sohn and Chai, 2005), in Romania was $10.1 \%$ in household cats (Mircean et al., 2010) and in Colombia which was $7.4 \%$ in house cats (Echeverry et al., 2012), low prevalence of hookworm also reported in Spain (Gracenea et al., 2009) found A.tubaeforme eggs in $4 \%$ of feline fecal samples. Hookworm larvae that normally mature in the intestinal tracts of animals can cause cutaneous larva migrans in people. Zoonotic hookworms known to cause this condition include A.braziliense, A. caninum, A. ceylanicum, A.tubaeforme, Uncinaria stenocephala and Bunostomum phlebotomum. Other species of hookworms found in animals, including wildlife and captive exotics, might also be able to cause cutaneous larva migrants (Acha and Szyfres, 2003).
Cats are the definitive host of some Cestodes or well known as tapeworm. Cestodes that have been reporting infected cats were Diphyllobothrium Spp, Joyeuxiella Spp, Spirometra Spp, Dipyllidium caninum, Taenia taeniaeformis and Echinococcus Spp. The prevalence of Diphyllobothrium Spp found from stray cats in this research was the highest $(52,38 \%)$. Other research reported that in Iranian stray cats detected Cestodes were Joyeuxiella pasqualei (34.3\%), Dipyllidium caninum (49.5\%), Taenia taeniaeformis (12.3\%) and Spirometra Spp (3.8\%) (Zibaei et al.,2007). The prevalence of cat Cestodes in Japan reported Spirometra erinaceieuropaei (8.3\%), Dipyllidium caninum (1.4\%), Taeniidae $(0.2 \%)$ and Diphyllobothrium nihonkaiense $(0.1 \%)$ (Yamamoto et al., 2009). Diphyllobothrium latum is a tapeworm that has a serious attention of public health because it is a zoonotic agent. Some previous studies reported that thus tapeworms were infecting humans (Revenga, 1993).

The freshwater fishes, such as pikes, burbots, trouts, salmons, and perches were listed as the second intermediate hosts for Diphyllobothrium Spp,. However, the species of the broad fish tapeworm such as Diphyllobothrium latum, transmitted by salmonid fish was put to question, and the one in Japan by was assigned as a new species Diphyllobothrium nihonkaiense (Yamamoto et al., 2009), and another in Siberia transmitted by 2 salmonid fish species, was assigned as Diphyllobothrium klebanovskii (Nicoulaud et al., 2005). Banyuwangi District is an area which is surrounded by sea. Therefore, stray catsinfecting Diphyllobothrium Spp in Banyuwangi City may be causes by consuming saltwater fishes. It is very possible because saltwater fishes are the biggest marine commodity in Banyuwangi City and also many traditional market sell saltwater fishes in this area. The saltwater fishes also become a potential intermediate host for Diphyllobothrium Spp in Banyuwangi City and it is important to conduct more deeper research study because based on 
this research result, prevalence of Diphyllobothrium Spp was the highest (52,38\%).

The high overall prevalence of gastrointestinal parasites of cats obtained in this study is considered to be critical from the viewpoint of public health importance. Some of these parasite species are responsible for several zoonotic diseases such as visceral larva migrans and ocular larva migrans caused by infection with Toxocara cati in humans. Therefore, there is the need to put in place appropriate control strategies by the public health authorities in these communities such as increasing the awareness of feline zoonotic parasites in the population which could be helpful to prevent or minimize zoonotic transmission. In addition, establishing a control programs to diagnose, treat and control gastrointestinal parasites of companion animals including cats in these area is highly recommended.

\section{CONCLUSION}

It can be concluded that the prevalence of gastrointestinal helminth parasites in stary cats in Banyuwangi City was high. The helminth parasites that found in this research were Toxocara Spp (43,65\%), Ancylostoma Spp $(3,96 \%)$ and Diphyllobothrium Spp (52,38\%).

\section{ACKNOWLEDGEMENTS}

Many thanks to the Rector of Universitas Airlangga, Dean of Faculty of Veterinary Medicine, Chief of Veterinary Medicine PSDKU Banyuwangi of Universitas Airlangga and also all colleagues who have supported this research.

\section{REFERENCES}

Abu-Madi, M.A., D.A. Al-Ahbabi, M.M. AlMashadani, R. Al-Ibrahim, P. Pal, J.W. Lewis. 2008. Patterns of parasitic infections in faecal samples from stray cat populations in Qatar. J. Helminth 81: 281-286.

Acha, P.N., B. Szyfres. 2003. Zoonoses and communicable diseases common to man and
Animals: Cutaneous larva migrans; Parasitoses. Sci Tech Pub 580: 249-52.

Agustina, K.K. 2013. Identification and prevalence of strongyle type worm in pigs in Bali Indonesia. Bul Vet Udayana 5(2): 131138.

Coelho, W.M.D., A.F.T. Amarante, J.C. Apolinario, N.M.D. Coelho, K.D.S. Bresciani. 2011. Occurrence of Ancylostoma in dogs, cats and public places from Andradina city, Sao Paulo State, Brazil. Rev Inst Med Trop Sao Paulo 53(4): 181-184.

Duarte, A., I. Castro, I.M. Pereira da Fonseca, V. Almeida, L.M. Madeira de Carvalho, J. Meireles, M.I. Fazendeiro, L. Tavares, Y. Vaz. 2010. Survey of infectious and parasitic diseases in stray cats at the Lisbon Metropolitan Area, Portugal. J Feline Med Surg 12(6): 441-446.

Echeverry, D.M., M.I. Giraldo, J.C. Castaño. 2012. Prevalence of intestinal helminths in cats in Quindío, Colombia. J Biomedica 32(3): 430-436.

Epe, C., N. Coati, T. Schnieder. 2004. Results of parasitological examinations of faecal samples from horses, ruminants, pigs, dogs,cats, hedgehogs and rabbits between 1998 and 2002. Dutsch Tierärztl Wochenschr 111: 243-247.

Glinz, D., D. Kigbafori, K.D. Silué, S. Knopp, L.K. Lohourignon, K.P. Yao, P. Steinmann, L. Rinaldi, G. Cringoli, E.K. N'Goran, J. Utzinger. 2010. Comparing Diagnostic Accuracy of Kato-Katz, Koga Agar Plate, Ether-Concentration, and FLOTAC for Schistosoma mansoniand Soil-Transmitted Helminths. Plos Neglected Trop Dis 4(7): 110.

Gracenea, M., M.S. Gomez, J. Torres. 2009. Prevalence of intestinal parasites in shelter dogs and cats in the metropolitan area of Barcelona (Spain). Acta Parasitol 54: 73-77. 
Holland, C.V., H.V. Smith. 2006. Toxocara the enigmatic parasite. Wallingford UK, $C A B I$ Publishing 301.

Labarthe, N., M.L. Serrao, A.M.R. Ferreira, N.K.O. Almeida, J. Guerrero. 2004. A survey of gastrointestinal helminths in cats of the metropolitan region of Rio de Janeiro, Brazil. Vet. Parasitol 123: 133-139.

Luty, L. 2001. Prevalence of Species of Toxocara in dogs, cats and red foxes from the Poznan region, Poland. J. Helminthol 75: 153-156.

Marti, H.P., E. Escher. 1990. SAF: an alternative fixing solution for parasitological stool test. Schweiz Med Wochenschr 120:1473-1476.

Mircean, V., A. Titilincu, C. Vasile. 2010. Prevalence of endoparasites in household cat (Felis catus) populations from Transylvania (Romania) and association with risk factors. Vet Parasitol 171(1-2): 163-166.

Nealma, S., I.M. Dwinata, I.B.M. Oka. 2013. The Prevalence of Toxocara cati in local cat in Denpasar. Indonesia Medicus Veterinus 2(4): 428-436.

Nicoulaud, J., H. Yéra, J. Dupouy-Camet. 2005. Prevalence of Diphyllobothrium latum, L., 1758 infestation in Perca fluviatilis from Lake Leman. Parasite 12(4): 362-364.

Overgaauw, P.A.M. 1997. Aspect of Toxocara epidemiology: Toxocarasis in dogs and cats. Critical Rev Microbiol 23: 233-251.
Raji, A.A., A.A. Magaji, M.B. Bello, M.D. Lawal, A. Mamuda, M.S. Yahaya. 2013. Prevalence of gastrointestinal parasites of stray cats: a case study of two hospitals in Sokoto Metropolis, Sokoto, Nigeria. J. Bacteriol Parasitol 4(4): 1-3.

Revenga, J.E. 1993. Diphyllobothrium dendriticum and Diphyllobothrium latum in fishes from southern Argentina: association, abundance, distribution, pathological effects, and risk of human infection. J. Parasitol 79(3): 379-383.

Riggio, F., R. Mannella, G. Ariti, S. Perrucci. 2013. Intestinal and lung parasites in owned dogs and cats from central Italy. Vet. Parasitol 193(1-3): 78-84.

Sohn, W.M., J.Y. Chai. 2005. Infection status with helminthes in feral cats purchased from a market in Busan, Republic of Korea. Korean J. Parasitol 43(3): 93-100.

Ward, E. 2009. Roundworm Infection in Cats. Kingsbrook Animal Hospital 1-3.

Yamamoto, N., M. Kon, T. Saito, N. Maeno, M. Koyama, K. Sunaoshi, M. Yamaguchi, Y. Morishima, M. Kawanaka. 2009. Prevalence of intestinal canine and feline parasites in Saitama Prefecture, Japan. Kansenshogaku Zasshi 83(3): 223-228.

Zibaei, M., S.M. Sadjjadi, B. Sarkari. 2007. Prevalence of Toxocara cati and other intestinal helminths in stray cats in Shiraz, Iran. J. Trop Biomed 24(2): 39-43. 